\title{
STUDYING THE EFFECT OF BUTANOL ON THE ANODE BEHAVIOR OF COPPER IN PHOSPHORIC ACID SOLUTIONS
}

\author{
Darja Sil'chenko1, Ganna Reznichenko², Olena Maksimenko1, \\ Hanna Pancheva ${ }^{1}$, Evgeniia Mykhailova ${ }^{3}$, Oleksiy Pylypenko $^{4, 凶}$
}

https://doi.org/10.23939/chcht16.01.103

\begin{abstract}
The anode behavior of the copper electrode immersed in butanol phosphate electrolytes has been studied. The polarization dependences of the electrode allowed us to detect the sections that correspond to the passive and active states of copper and we also established the zone of the combined behavior of the processes of the copper dissolution and oxygen release. It was also established that a butyl alcohol contributes to an abrupt decrease in current densities in the entire region of anode potentials. The addition of butanol conditions the disappearance of current oscillations that can be seen on polarization dependences in phosphate solutions. Evidently, a decrease in the current densities is a consequence of the butanol adsorption on the copper surface and its participation in the formation of passive films. The specific features of the copper passivation in butanol phosphate electrolytes are characterized by the appearance of the explicit current peak that separates active and passive state zones at the ratio of $\mathrm{C}_{4} \mathrm{H}_{9} \mathrm{OH}: \mathrm{H}_{3} \mathrm{PO}_{4}=1: 3$. As the alcoholto-acid ratio increases, the peak gradually decreases. The addition of butanol has no determining influence on the potential value that corresponds to the started oxygen release. Current efficiency values for the copper dissolution depend on the anode current density $j_{a}$ and the electrolyte composition. An increase in $j_{\mathrm{a}}$ results in a decreased current efficiency value. An increase in the $\mathrm{C}_{4} \mathrm{H}_{9} \mathrm{OH}$ content has a similar action. Maximum current efficiency values are observed at $j_{\mathrm{a}}=0.5-2 \mathrm{~A} \cdot \mathrm{dm}^{-2}$, and they correspond to the active copper state. The dependences obtained for the copper dissolution rate allowed us to establish that $v_{p}$ also increases with an increase in the current density up to $j_{\mathrm{a}}=$ $=20 \mathrm{~A} \cdot \mathrm{dm}^{-2}$. The copper treatment quality depends on the current density and the electrolyte composition. The
\end{abstract}

\footnotetext{
${ }^{1}$ National Technical University "Kharkiv Polytechnic Institute"

2 Kyrpychova St., Kharkiv 61002, Ukraine

${ }^{2}$ National University of Civil Defence of Ukraine

94 Chernyshevska St., Kharkiv 61023, Ukraine

${ }^{3}$ Simon Kuznets Kharkiv National University of Economics

9-A Nauky Ave., Kharkiv 61166, Ukraine

${ }^{4}$ O.M.Beketov National University of Urban Economy in Kharkiv,

17 Marshal Bazhanov St., Kharkiv 61002, Ukraine

opilipenko1984@gmail.com

(C) Sil'chenko, D.; Reznichenko, G.; Maksimenko, O.; Pancheva, H.; Mykhailova, E.; Pylypenko, O., 2022
}

solutions with the ratio of $\mathrm{C}_{4} \mathrm{H}_{9} \mathrm{OH}: \mathrm{H}_{3} \mathrm{PO}_{4}=2: 1$ fail to provide a high quality treatment; the surface is not glossy and it has grinding traces. A high-quality treatment is observed in the electrolytes with the ratio of $\mathrm{C}_{4} \mathrm{H}_{9} \mathrm{OH}: \mathrm{H}_{3} \mathrm{PO}_{4}=1: 2$ and lower. The electrochemical polishing in such solutions results in the glossy copper surface with the smoothed relief and it has no polishing traces.

Keywords: electrochemical polishing, passivation, butyl alcohol, surface-active substance, polarization dependence.

\section{Introduction}

The metals are subjected to the electrochemical polishing to provide defect-free surfaces with the smoothed relief. The principle of electrochemical polishing consists in the anode dissolution of the treated metal in the appropriate electrolyte solution. The surface becomes smooth due to the specific features of the behavior of the pool of chemical and electrochemical processes at the metal-electrolyte interface and it eventually leads to the primary dissolution of the microelevations of the metal profile. The electrochemical polishing is used for the treatment of the items prior to the application of galvanic coatings or for the treatment of already applied coatings and it is ${ }^{1-3}$ also used for the removal of the burrs and scratches, ${ }^{4}$ for the tool sharpening and for the preparation of metallographic sections. ${ }^{5-8}$ The electrochemical polishing is also used for the ornamental finishing of different items.

First research papers on the electrochemical copper polishing are more than 90 -years old. ${ }^{9}$ Over this period of time an ample amount of the solution compositions intended for the treatment of copper and its alloys were suggested in the periodicals and patent literature. In most cases, the phosphoric acid acts as a main component. The difference is reduced to the addition of inorganic and organic compounds that have a favorable effect on electrolyte performance characteristics and improve the copper surface treatment quality. The prevalence of phosphate electrolytes is conditioned by their multipur- 
poseness and efficiency. They can also be used for the polishing of copper alloys. Phosphate solutions have the lowest corrosive power in comparison to other acid solutions and they are not so grave for the environment. Copper, which was dissolved on the anode, is deposited onto the cathode and partially precipitated onto the bath bottom in the form of sludge simplifying thus the electrolyte regeneration and makes the reuse of metal possible.

To improve the treatment quality, inorganic and organic substances are added to phosphate electrolytes. The most frequently used additives are alcohols that have surface-active properties and facilitate the smoothing of the microroughness on the copper surface. In the case of the electrochemical polishing, it is very important to establish the relationship between the treatment mode, the current output and the dissolution rate including the influence of the additive on the copper surface morphology. These data cannot be found in available sources and this fact conditions the vitality of the additional research to be done in this field.

To improve the polishing quality, we suggest adding of inorganic and organic substances to phosphate electrolyte. ${ }^{10}$ Chromic anhydride and sulfuric acid were added to the phosphate electrolyte as inorganic additives. The drawback of the electrolytes is the toxicity of $\mathrm{CrO}_{3}$, and the attempts are made to restrict its use. It should be noted that the result was the increased electrolyte corrosivity.

The electrolytes with organic additives, in particular alcohols, amines, amides and carbonic acids are more popular. ${ }^{8-26}$ The researchers accumulated a huge data array relating to the studies of the properties of such electrolytes, including adsorption properties and the copper dissolution kinetics. Many organic substances have surface-active properties and therefore they provide a high quality of the copper treatment. The organic additives adsorbed by the anode surface, form a layer with a high resistance property; however, its thickness is thinner on the surface microelevations. The passive layer blocks the anode surface and we observe a preferential dissolution of the sections with the film of a minor thickness.

Alcohols are the most widely spread organic additives. The availability of the molecule polarity conditions the surface-active properties of alcohols that in addition to their harmlessness explain a wide application of the compounds of this class for the electrochemical polishing of copper and copper alloys. For example, the studies of the monoatomic alcohols effect on polarization dependences, the current collection and its distribution showed the appropriateness of the alcohols addition for the treatment of the copper-manganese-zinc alloy. ${ }^{17}$ The obtained data cannot be used for copper due to different composition of the treated metal. Some scientific papers state that methanol, ethanol, propanol and isopropanol have a strong inhibiting action with regard to the copper dissolution process ${ }^{18,19}$ The results are of interest from the standpoint of the anode process kinetics. However, the data on the additives effect on the copper morphology, the current output and the dissolution rate are unavailable. The same can be said about the researches, which state that a good smoothing of the roughness on the copper surface is achieved by the addition of glycerin, ${ }^{20}$ ethylene glycol, ${ }^{21}$ phenols ${ }^{22}$ and monoatomic alcohols. ${ }^{23}$ The investigations show that butanol is an efficient copper dissolution inhibitor and provides a better quality of the copper treatment in comparison to ethyl alcohol. ${ }^{24-26}$

Hence, the addition of alcohols to phosphate electrolytes conditions a decrease in the copper dissolution rate and facilitates its passivation. ${ }^{25}$ As a rule, this results in a higher quality of the metal treatment. However, the research done is lacking the data that show the additive effect on the surface morphology and the copper dissolution rate and show the need for the additional research.

The purpose of this research is to study the anode behavior of copper in phosphate butanol electrolytes.

To attain this goal the following problems were set:

- getting polarization dependences for the copper electrode placed in phosphate and phosphate butanol electrolytes;

- studying the influence of the electrolyte composition and the treatment mode on the surface morphology and the copper dissolution rate during the anode treatment.

\section{Experimental}

The specimens made of the copper strip (copper M00) were used for the investigations. The coaxially arranged cylinder made of copper of the same type served as an additional electrode. The ratio of $S_{\mathrm{r}}: S_{\mathrm{a}}=100: 1$.

The specimens were prepared by grinding with the sanding disk and degreasing using benzine and the water suspension of $\mathrm{Na}_{2} \mathrm{CO}_{3}$ and rinsing with the tap and distilled water. The initial polishing was conducted using the abrasive wheel KSL 150x30x32 P10ZAK. The final polishing was conducted using the abrasive wheel KSL 150x30x32 P40ZAK. The roughness of the prepared specimens was measured using the section gauge HOMMEL $\mathrm{T} 1000$. The measurements were taken at five sections of each specimen to define the roughness average $R_{\mathrm{a}}$. Based on the measurement data we managed to get the polished surface with $R_{\mathrm{a}}=2.78-3.57 \mu \mathrm{m}$ that corresponds to the surface finish fifth class.

Polarization dependences were got using the potentiostat Ellins $\mathrm{P}-45 \mathrm{X}$ at the potential scanning rate of 
$5 \mathrm{mV} \cdot \mathrm{s}^{-1}$. Working electrode potentials were measured relatively the saturated chloride-silver electrode placed in a separate vessel and connected to the cell by the key. In the text, potential values are given by the scale of this electrode.

The stationary electrolysis was conducted under the galvanostatic mode using the power supply source B5-47, voltammeter M2038 and the multimeter Keithley-2000.

The metallographic microscope Leica DM ILM with the digital video camera Leica DFC 295 was used to take the pictures of the surface of treated specimens. The electrolytes were prepared for the investigation using $\mathrm{H}_{3} \mathrm{PO}_{4}(85 \%)$ and $\mathrm{C}_{4} \mathrm{H}_{9} \mathrm{OH}(99.7 \%)$ of an analytical reagent grade.

\section{Results and Discussion}

The electrochemical behavior of copper in the solutions containing the phosphoric acid is similar to the behavior of metals disposed to the passivation during the anode polarization. The polarization dependences of such metals allow us to separate the areas of the active dissolution, transition to the passive state, the passive state, repassivation with the formation of the ions with a higher oxidation degree and attainment by the potential that corresponds to the oxygen release. The organic surface-active substances adsorbed by the anode surface inhibit, as a rule, the copper dissolution process. The combination of passivation and adsorption processes is supposed to result in the improved treatment quality with a good smoothing of the surface microroughness. An efficient smoothing can be provided by butanol that can be adsorbed by the anode surface and it can reduce the surface tension at the interface. The butanol adsorption will facilitate a deep copper passivation and inhibit the dissolution. These assumptions are confirmed by the obtained polarization dependences (Fig. 1a).

The results given in Fig. 1 show that the butanol addition changes the shape of polarization dependences. The dependence obtained for the $85 \%$ solution of $\mathrm{H}_{3} \mathrm{PO}_{4}$, (Fig. 1b, curve 1) has a shape typical for the metal that is disposed to the transition to the passive state. As the acid concentration is reduced, the current density is increased and the oscillations conditioned by the cyclic copper passivation/activation process (Fig. 1b, curves 2 and 3 ) appear on the curves at the ratio of $\mathrm{H}_{3} \mathrm{PO}_{4}: \mathrm{H}_{2} \mathrm{O}=1: 2$ and lower. ${ }^{27}$ The polarization dependence of copper in the phosphate butanol solution at the ratio of $\mathrm{C}_{4} \mathrm{H}_{9} \mathrm{OH}: \mathrm{H}_{3} \mathrm{PO}_{4}=1: 1$ is characterized by the availability of an explicit peak, which separates the regions of the active and passive states of copper (Fig. 1a, curve 1). With an increase in the butanol content the peak is decreased and at the ratio of $\mathrm{C}_{4} \mathrm{H}_{9} \mathrm{OH}: \mathrm{H}_{3} \mathrm{PO}_{4}=3: 1$ it is degenerated (Fig. 1a, curve 3). The addition of butanol to the electrolyte composition inhibits the copper dissolution and contribues to an abrupt decrease in the current density in the entire region of the investigation of anode potentials. Butanol causes the disappearance of current oscillations observed in phosphate electrolytes. A decrease in the current densities is a consequence of the butanol adsorption on the copper surface and participation in the formation of the films with a deeper anode passivation.

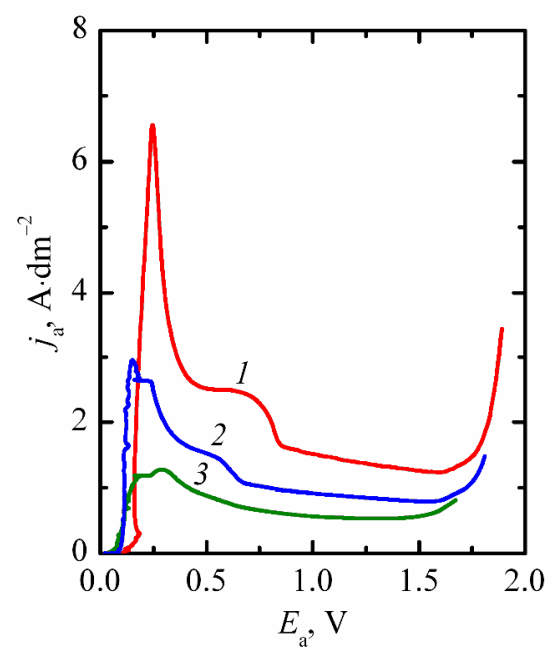

a)

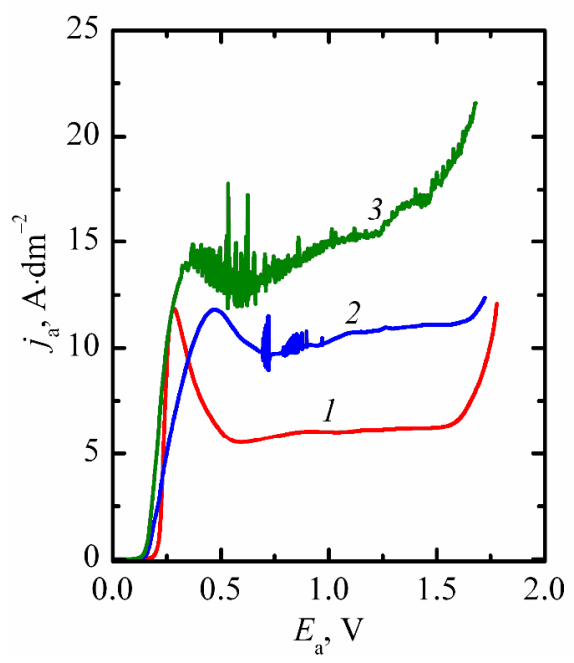

b)

Fig. 1. The anode polarization dependences of the copper electrode in phosphate-butanol (a) and phosphate (b) electrolytes. $\mathrm{C}_{4} \mathrm{H}_{9} \mathrm{OH}: \mathrm{H}_{3} \mathrm{PO}_{4}(\mathrm{v} / \mathrm{v})$ is equal to $1: 3(1) ; 1: 1$ (2) and $3: 1(3) . \mathrm{H}_{3} \mathrm{PO}_{4}: \mathrm{H}_{2} \mathrm{O}(\mathrm{v} / \mathrm{v})$ is equal to $17: 3(1) ; 2: 1(2)$ and $3: 1(3)$ 
The transition of copper to the passive state in the phosphate-butanol solutions has also its specific features. In $\mathrm{H}_{3} \mathrm{PO}_{4}$ solutions, the curve section responsible for the transition to the passive state is characterized by the smooth decrease in the current value (Fig. 1b, curve 1). In the solutions with the addition of butanol the transition to the passive state is accompanied by the appearance of two current plateaus on the curves (Fig. 1a, curves 1 and 2). The range of potentials, at which the plateau is observed, is not constant and it is shifted to the domain of negative values with an increase of the butanol content in the solution. Evidently, the appearance of two plateaus is a consequence of the specific features of the butanol adsorption on the copper surface. A change in the concentration of phosphoric acid and butanol has actually no influence on the anode potential value that corresponds to the oxygen release onset. Alcohol reduces the rate of copper dissolution and leads to an improvement in the processing quality with good smoothing of surface microroughnesses. ${ }^{28,29}$ In addition, butanol decreases the surface tension at the interface and also causes the copper surface to be smoothed. ${ }^{26}$

Fig. 2 gives the data obtained during the electrolysis under the stationary galvanostatic mode. The given data allow us to draw a conclusion that current efficiency values for the copper dissolution depend on the solution composition to a great extent. An increase in the butanol concentration results in decreased current efficiency values. This influence becomes especially noticeable at $j_{\mathrm{a}}<2 \mathrm{~A} \cdot \mathrm{dm}^{-2}$ that corresponds to the combined copper dissolution and oxygen release process. Maximum current efficiency values are observed for the solutions with the ratio of $\mathrm{C}_{4} \mathrm{H}_{9} \mathrm{OH}: \mathrm{H}_{3} \mathrm{PO}_{4}=3: 1$. In the range of $j_{\mathrm{a}}=0.5-2 \mathrm{~A} \cdot \mathrm{dm}^{-2}$, current efficiency values are expectedly high and the effect of the solution composition is not so strong. In some cases, the electrolysis at $j_{\mathrm{a}}=0.5-$ $1.0 \mathrm{~A} \cdot \mathrm{dm}^{-2}$ resulted in the generation of the current output values which exceed $100 \%$. The generation of too high values of the current efficiency is explained by the fact that the copper dissolution in this range of $j_{\mathrm{a}}$ is accompanied by the formation of the sludge. The sludge has a weak cohesion to the anode surface and it is removed by the rinsing and drying of the tested specimen after the experiment. The sludge weight conditions an additional decrease in the mass that results in the generation of the high values of the current efficiency for copper. The obtained sludge was treated with the fivepercent sulfuric acid and after one hour of the exposure using a small amount of the solution, we could see the appearance of the light-blue discoloring of the latter. It is indicative of the presence of copper oxide in the sludge. The gravimetric measurement data allowed us to establish that a decrease in the sludge mass after curing in acid solution is $0.8-1.5 \%$. Evidently, the appearance of oxide can be explained by the electrochemical oxidation of the anode surface or the chemical oxidation that occurs after its exposure to the air. However, the formation of the bivalent copper oxide is also observed during the electrochemical polishing of copper where it is a probable by-product. ${ }^{30,31}$ Anyway it is much more likely that oxide is formed during the sludge contact with the air, when the processes of its extraction, rinsing and especially drying take place.

Gravimetric measurements allowed us to calculate the copper dissolution rate. From the technological point of view this parameter is important because it gives us an opportunity to estimate a change in the metal thickness during the treatment. It is very important to know the copper dissolution rate for the electrochemical polishing of the parts with precise sizes or bold parts. The obtained data (Fig. 2b) show that the dissolution rate depends on the used current density and the electrolyte composition. An increase in the current density results in an increased copper dissolution rate in spite of the fact that a decrease in the current efficiency for the copper dissolution is observed with an increase in $j_{\mathrm{a}}$. In the solutions with the $\mathrm{C}_{4} \mathrm{H}_{9} \mathrm{OH}: \mathrm{H}_{3} \mathrm{PO}_{4}$ ratio equal to $1: 2$ and $1: 3$ an increase in the copper dissolution rate is observed up to $j_{\mathrm{a}}=20 \mathrm{~A} \cdot \mathrm{dm}^{-2}$. After reaching this value the rate is decreased due to a decrease in current efficiency values (Fig. 2b, curves 1 and 2).

The copper treatment quality is defined by the current density and the electrolyte composition (Figs. 3 and 4). The unsatisfactory smoothing is observed in the solutions with the ratio of $\mathrm{C}_{4} \mathrm{H}_{9} \mathrm{OH}: \mathrm{H}_{3} \mathrm{PO}_{4}=2: 1$ and higher (Fig. 3a, b) and the scratches remain on the copper surface after the grinding with the abrasive flap wheel. The copper surface is not very glossy. With a decrease in the alcohol amount the copper surface treatment quality is improved. A high quality treatment is observed in the solutions with the ratio of $\mathrm{C}_{4} \mathrm{H}_{9} \mathrm{OH}: \mathrm{H}_{3} \mathrm{PO}_{4}=1: 2$ and lower (Fig. 3d, e). The electrochemical polishing in the solutions of such composition results in the disappearance of the scratches after polishing and the surface becomes glossy. However, the treatment in these solutions is accompanied by the removal of a larger layer of the metal in comparison with the solutions with a high content of $\mathrm{C}_{4} \mathrm{H}_{9} \mathrm{OH}$.

Table 1 gives as an example the data that characterize the removal of metal and the final surface roughness that can be got after the 3-minute electrochemical treatment at the current density of $10 \mathrm{~A} \cdot \mathrm{dm}^{-2}$ in the electrolytes with different alcohol-toacid ratios. 


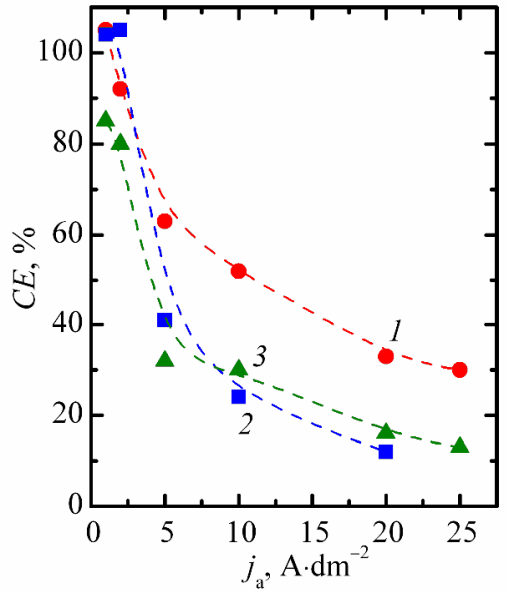

a)

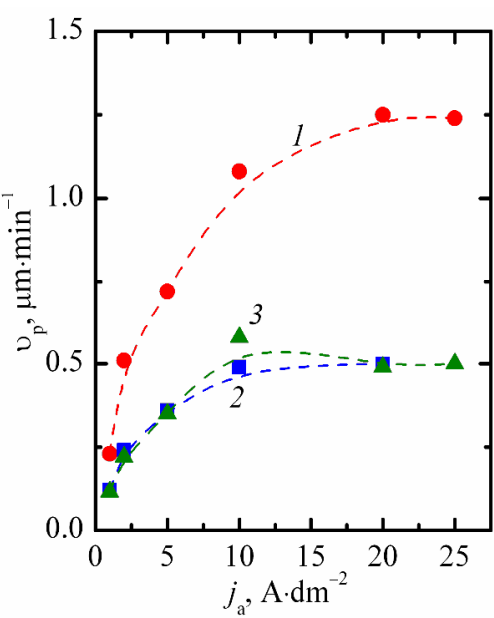

b)

Fig. 2. The dependences of the current efficiency (a) and the dissolution rate (b) on the current density for the anode treatment of copper in phosphate-butanol solutions. $\mathrm{C}_{4} \mathrm{H}_{9} \mathrm{OH}: \mathrm{H}_{3} \mathrm{PO}_{4}$ ratio $(\mathrm{v} / \mathrm{v})$ is equal to $1: 1(1) ; 2: 1$ (2) and 3:1 (3)

Table 1. The thickness of the dissolved copper layer during electrochemical polishing in solutions with different ratios of alcohol:acid

\begin{tabular}{|c|c|c|}
\hline Ratio $\mathrm{C}_{4} \mathrm{H}_{9} \mathrm{OH}: \mathrm{H}_{3} \mathrm{PO}_{4}$ & Thickness of the dissolved metal layer, $\mu \mathrm{m}$ & Roughness $R_{\mathrm{a}}, \mu \mathrm{m}$ \\
\hline $3: 1$ & 1.88 & 1.94 \\
\hline $2: 1$ & 1.52 & 1.11 \\
\hline $1: 1$ & 3.01 & 0.64 \\
\hline $1: 2$ & 3.78 & 0.48 \\
\hline $1: 3$ & 3.94 & 0.56 \\
\hline
\end{tabular}

The obtained values of the surface roughness of polished specimens show that the surface smoothing and its leveling are observed in all cases and moreover, this effect becomes more explicit when the solutions with a lower alcohol content are used. The polished surface quality corresponds to the class 6 or 7 that is one or two orders of magnitude greater in comparison to the initial one.

An optimal range of current densities is available that enables a high-quality copper treatment (Fig. 4). At $j_{\mathrm{a}}=0.5-1 \mathrm{~A} \cdot \mathrm{dm}^{-2}$, the copper surface becomes opaque during the anode polarization and it acquires a brown color conditioned by the presence of oxide films or pickling sludge. With an increase in $j_{\mathrm{a}}$ to $5 \mathrm{~A} \cdot \mathrm{dm}^{2}$ the treatment quality is improved though the polishing scratches are still present. It is evident that the adopted three-minute electrolysis duration is insufficient for the surface smoothing in the electrolytes with the high alcohol content. The best quality of copper treatment is observed when the value of $j_{\mathrm{a}}$ is increased to the values of $10 \mathrm{~A} \cdot \mathrm{dm}^{-2}$ and higher. Despite the fact that the treatment at such $j_{\mathrm{a}}$ values occurs in the mode of the combined progress of the reactions, we observe a good smoothing of the copper surface and the pit etching is unavailable.

We should keep in our mind that the expected smoothed surface relief and high surface luster are accompanied by a considerable amount of the removed metal. In practice, it implies the need for a considerable tolerancing of machined parts and an increased reagent consumption, which is conditioned by the electrolyte outflow with gasses liberated by the electrodes. In this case, the optimal option will be an extensive mechanical treatment that includes a fine surface finishing or polishing. In this case, the duration of electrochemical treatment can be reduced to 20 or 30 seconds and it will be a finishing operation that will correspond to a final finish of the particular product.

A favorable influence of butanol on the electrochemical polishing process becomes especially obvious when comparing the images of the specimens treated in the solutions with the addition of $\mathrm{C}_{4} \mathrm{H}_{9} \mathrm{OH}$ (Figs. 3 and 4) and without it (Fig. 5).

The electrochemical polishing in phosphoric acid solutions results in the appearance of multiple pitting on the copper surface caused by the local breakdown of the passive film on the metal in anode polarization conditions. ${ }^{26}$ It is believed that the appearance of local breakdowns is most probable when the potentials correspond to the oxygen release onset. ${ }^{21}$ However, in the case of the anode polarization in phosphate solutions the local corrosion is often observed prior to the achievement of the critical potential that can be caused by the local disintegration of the passive film continuity. ${ }^{32,33}$ 


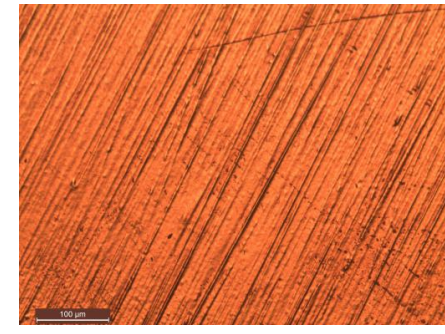

a)

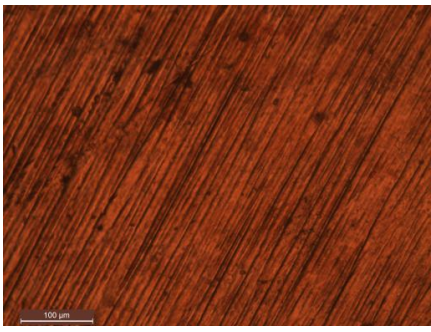

b)

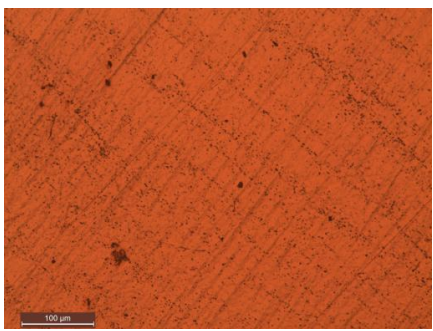

c)

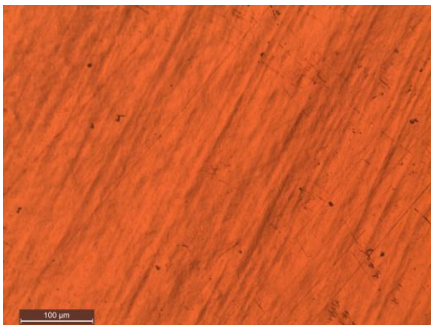

d)

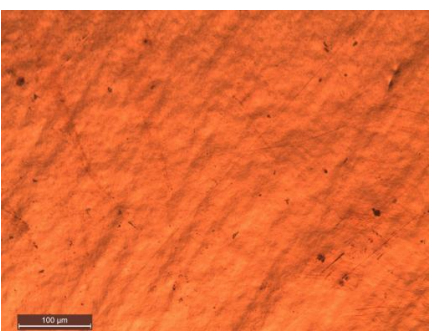

e)

Fig. 3. The pictures of the copper surface taken after the treatment in the phosphate-butanol solutions at $j_{\mathrm{a}}=20 \mathrm{~A} \cdot \mathrm{dm}^{-2}$. $\mathrm{C}_{4} \mathrm{H}_{9} \mathrm{OH}: \mathrm{H}_{3} \mathrm{PO}_{4}(\mathrm{v} / \mathrm{v})$ is equal to $3: 1(\mathrm{a}) ; 2: 1$ (b); 1:1 (c); $1: 2$ (d) and $1: 3(\mathrm{e})$

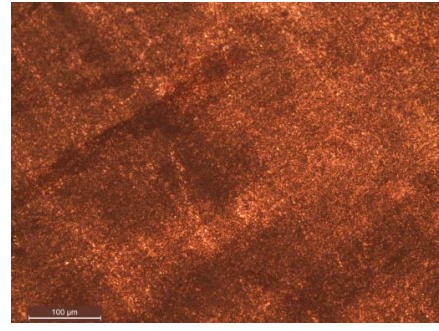

a)

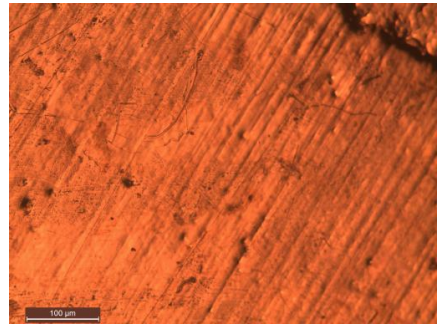

b)

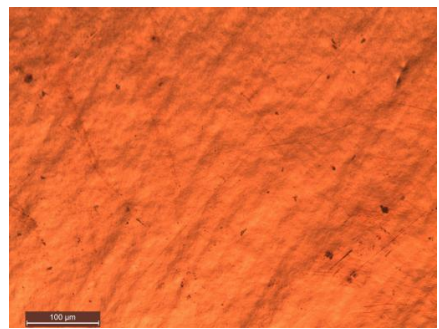

c)

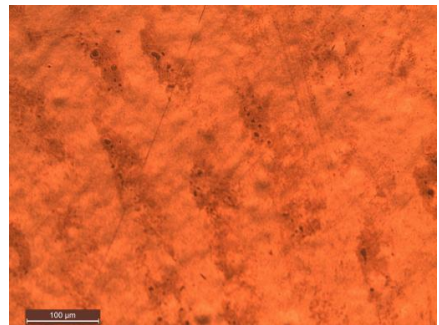

d)

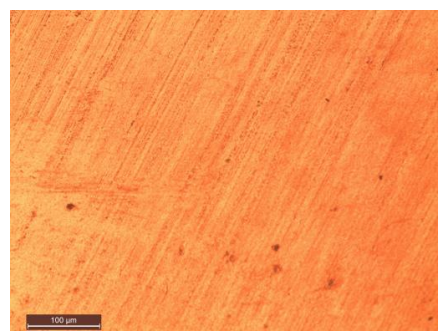

e)

Fig. 4. The pictures of the copper surface taken after the electrochemical polishing in phosphate-butanol solutions for $\mathrm{C}_{4} \mathrm{H}_{9} \mathrm{OH}: \mathrm{H}_{3} \mathrm{PO}_{4}=1: 3(\mathrm{v} / \mathrm{v})$ and different $j_{\mathrm{a}}, \mathrm{A} \cdot \mathrm{dm}^{-2}: 1$ (a); 5 (b); 10 (c); 15 (d) and 20 (e) 


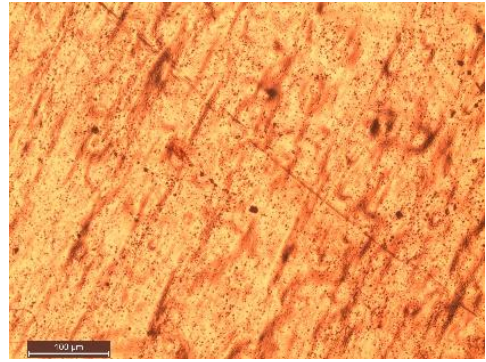

a)

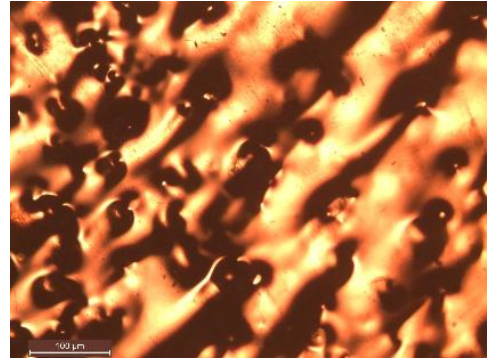

b)

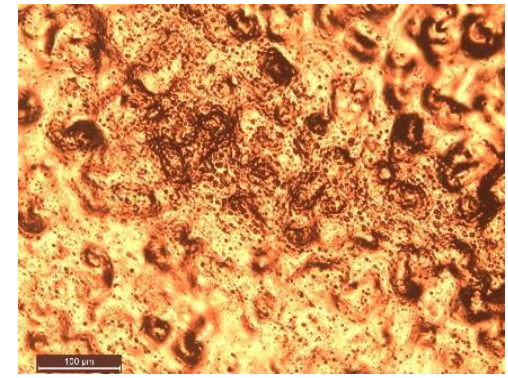

c)

Fig. 5. The pictures of the copper surface taken after the electrochemical polishing in the phosphate solutions at $j_{\mathrm{a}}=20 \mathrm{~A} \cdot \mathrm{dm}^{-2} \cdot \mathrm{H}_{3} \mathrm{PO}_{4}: \mathrm{H}_{2} \mathrm{O}(\mathrm{v} / \mathrm{v})$ is equal to $1: 1(\mathrm{a}) ; 1: 2(\mathrm{~b})$ and $1: 3(\mathrm{c})$

The most widely spread theory that explains the effect of electrochemical polishing is the theory of the film passivation, ${ }^{10}$ according to which the anode surface consists of active convex sections and passive concave sections. Such a situation is conditioned by the retarded behavior of diffusion processes from the metal surface to the electrolyte volume. The dissolution of copper results in the accumulation of dissolution products on the surface and formation of a viscous electrolyte layer with a high electrical resistance. The passive film formed on the anode surface provides the appearance of electrochemical polishing effect. Usually, the film is less thick at the microelevations and it creates the premises for the surface smoothing and its glossy appearance simultaneously with the better conditions for the removal of dissolution products. Electrochemical polishing conditions can assumingly be improved through the addition of the surface-active substances to the electrolyte that facilitate the wetting of the surface with the solution and participate in the formation of passive films of an adsorption type. ${ }^{28}$

The addition of butanol to the electrolyte contributes to a decrease in the surface tension at the boundary between the copper surface and the solution. ${ }^{26}$ When adsorbing, butanol participates in the formation of passive films. A decrease in the surface tension and participation in the film formation stipulate a decrease in the current density on the polarization dependences (Fig. 1a) and the roughness smoothing (Figs. 3 and 4) due to the decrease in the surface tension at the interface. The type of the dependences of the current efficiency and the copper dissolution rate (Fig. 2) is explained by the polarization curves for the copper electrode (Fig. 1a). The curves can conventionally be subdivided into the sections that correspond to the specific features of electrode processes that occur on copper in each specific range of the potentials. The section of the dependence that corresponds to the rise in current from the stationary potential value to a maximum value corresponds to the copper dissolution in the stationary mode with a high current efficiency.
The experimental values of the current efficiency in the range of $j_{\mathrm{a}}=0.5-2 \mathrm{~A} \cdot \mathrm{dm}^{-2}$ are $80-100 \%$. Proceeding from the assumption that copper is dissolved with the formation of two-valent ions, the current efficiency values exceeding $100 \%$ are impossible. This result is explained by the fact that the copper anode is dissolved nonuniformly with the sludge formation at these current densities. The sludge is easily removed by the specimen rinsing and this results in too high current efficiency values. Therefore, the copper surface treated at $j_{\mathrm{a}}=0.5-$ $2 \mathrm{~A} \cdot \mathrm{dm}^{-2}$ is considered to be rough and opaque. Sometimes, the films of a brown color are formed on the copper surface (Fig. 4a). These films consist of the oxide layers of a nonstochiometric composition, which is an ordinary phenomenon for the electrochemical metal oxidation. ${ }^{9,33}$ On attaining a maximum the curves show a decrease in the current value and it is indicative of the passive film formation. Copper is turned to the passive state and its dissolution in the plateau domain is controlled by the diffusion stage. There is an opinion that the electrochemical polishing occurs particularly in this domain. ${ }^{13} \mathrm{~A}$ further increase in the cell voltage results in the attainment of the oxygen release potential and it is characterized by the rise in current on polarization curves. In this case, a decrease in the copper dissolution current output value is observed (Fig. 2a). The treatment in these conditions allows us to obtain a smooth and glossy copper surface (Figs. 3c-d and 4c-d). A favorable effect of the butanol additive is vividly manifested in this case and it conditions an efficient smoothing, provides an abrupt decrease and even a complete removal of the copper etching. Though, the additive-free electrolytes also provide a glossy surface, however it has multiple etching points caused by the passive film breakdown. Additional explanations of the dependences in Fig. 2 can result in the measurement values of the current value of the potential of the copper electrode during the galvanostatic electrolysis (Table 2). 
Table 2. The current potential values of copper $E_{j}$ after five-minute electrolysis

\begin{tabular}{|c|c|c|c|c|c|c|c|}
\hline \multirow{2}{*}{ Solution composition } & \multicolumn{7}{|c|}{$E_{j}(\mathrm{~V})$ at $j_{\mathrm{a}}, \mathrm{A} \cdot \mathrm{dm}^{-2}$} \\
\cline { 2 - 9 } & 0.5 & 1 & 2 & 5 & 10 & 20 & 25 \\
\hline $\mathrm{C}_{4} \mathrm{H}_{9} \mathrm{OH}: \mathrm{H}_{3} \mathrm{PO}_{4}=1: 1$ & +0.11 & +0.25 & - & +2.50 & +3.28 & +4.77 & +5.52 \\
\hline $\mathrm{C}_{4} \mathrm{H}_{9} \mathrm{OH}: \mathrm{H}_{3} \mathrm{PO}_{4}=2: 1$ & - & +0.32 & +0.54 & +3.51 & +4.85 & +6.90 & +7.62 \\
\hline $\mathrm{C}_{4} \mathrm{H}_{9} \mathrm{OH}: \mathrm{H}_{3} \mathrm{PO}_{4}=3: 1$ & +0.52 & +2.14 & - & +5.07 & +8.18 & +8.15 & +8.10 \\
\hline $\mathrm{C}_{4} \mathrm{H}_{9} \mathrm{OH}: \mathrm{H}_{3} \mathrm{PO}_{4}=1: 2$ & - & +0.35 & +1.72 & +2.03 & +2.50 & +3.49 & +4.06 \\
\hline $\mathrm{C}_{4} \mathrm{H}_{9} \mathrm{OH}: \mathrm{H}_{3} \mathrm{PO}_{4}=1: 3$ & - & +0.41 & +1.08 & +1.88 & +2.31 & +3.11 & +3.49 \\
\hline
\end{tabular}

The values of $E_{j}$ show that an increase in the alcohol content in the solution unambiguously contributes to a deeper passivation of the copper anode. At current densities of $10-2 \mathrm{~A} \cdot \mathrm{dm}^{-2}$, the anode potential reaches $+(2-8) \mathrm{V}$, which is incredible when copper dissolves in an active state. The value of the current potential of the electrode is abruptly shifted to the domain of positive values as the butanol content is increased in the solution. Probably, this shift indicates that alcohol participates in the formation of adsorption films on the copper surface or forces out water molecules from the pre-anode electrolyte layer that serve as the acceptors for copper ions. ${ }^{34}$ In this case, it will be more correct to speak not even about the copper electrode potential but about the voltage drop in the "copper electrode-passive film" system that is the sum of the proper copper potential, the electrode polarization value and the voltage drop in the passive layer The adsorption of butanol is proved by the inhibited copper dissolution and decreased current densities in the entire potential range on polarization curves. The participation of butanol in the formation of passive films governs an effective decrease in the copper surface roughness even at $j_{\mathrm{a}}=10-25 \mathrm{~A} \cdot \mathrm{dm}^{-2}$ that are located in the domain of combined reactions (Fig. 1b).

\section{Conclusions}

It is shown that butanol is an efficient inhibitor of the copper dissolution in phosphate solutions that contributes to a decrease in current values in the entire range of anode potentials. An inhibiting effect is increased with an increase in the alcohol content and it is conditioned by its absorption on the copper surface with the formation of the insulating film that is expressed as a peak on polarization curves.

The gravimetric measurements that were carried out allowed us to establish that the current efficiency and the copper etching rate are defined by the electrolyte composition and the current density. With an increase in the alcohol content in the solution these indices are decreased especially at $j_{\mathrm{a}}>2 \mathrm{~A} \cdot \mathrm{dm}^{-2}$ that corresponds to the domain of combined reactions. The treatment data that were obtained for phosphate butanol solutions show that the surface smoothing and its improved brilliance can be carried out with a greater degree of efficiency in the solutions with the ratio of $\mathrm{C}_{4} \mathrm{H}_{9} \mathrm{OH}: \mathrm{H}_{3} \mathrm{PO}_{4}=1: 2$ and lower; however it is accompanied by a removal of the thicker layer of copper. On the whole, the roughness of the treated surface was reduced from $2.78-3.57$ to 0.56 $1.94 \mu \mathrm{m}$ and it is indicative of an increase in the surface treatment class by one or two orders of magnitude.

\section{References}

[1] Yang, G.; Wang, B.; Tawfiq, K.; Wei, H.; Zhou, S.; Chen, G. Electropolishing of Surfaces: Theory and Applications. Surf. Eng. 2017, 33, 149-166. http://dx.doi.org/10.1080/02670844.2016.1198452 [2] Abdel-Fattah, T.M.; Loftis, J.D. Comparison of the Electrochemical Polishing of Copper and Aluminum in Acid and Acid-free Media. ECS Trans. 2009, 25, 327-334.

https://doi.org/10.1149/1.3203970

[3] Chatterjee, B. Science and Industry of Electropolishing. Galvanotechnik 2015, 71, 71-93.

[4] Rotty, C.; Mandroyan, A.; Doche, M.-L.; Hihn, J.-Y. Electropolishing of CuZn Brasses and 316L Stainless Steels: Influence of Alloy Composition or PReparation Process (ALM vs. Standard Method). Surf. Coat. Techn. 2016, 307, 125-135. https://doi.org/10.1016/j.surfcoat.2016.08.076

[5] Wu, D.; Kang, R.; Guo, J.; Liu, Z.; Wan, C.; Jin, Z. On the Reaction Mechanism of a Hydroxyethylidene Diphosphonic AcidBased Electrolyte for Electrochemical Mechanical Polishing of Copper. Electrochem. Commun. 2019, 103, 48-54. https://doi.org/10.1016/j.elecom.2019.05.001

[6] Rokicki, R.; Hryniewicz, T. Enhanced Oxidation-Dissolution Theory of Electropolishing. Trans. Inst. Met. Finish. 2012, 90, 188196. https://doi.org/10.1179/0020296712Z.00000000031

[7] Li, D.; Li, N.; Xia, G.; Zheng, Z.; , Wang, J.; Xiao, N.; Zhai, W.; Wu, G. An in-situ Study of Copper Electropolishing in Phosphoric Acid Solution. Int. J. Electrochem. Sci. 2013, 8, 1041-1046.

[8] Smirnova, O.; Pilipenko, A.; Pancheva, H.; Smirnova, O.; Pilipenko, A.; Pancheva, H.; Zhelavskyi, A.; Rutkovska, K. Study of Anode Processes During Development of the New Complex Thiocarbamide-Citrate Copper Plating Electrolyte. EEJET 2018, 1, 47-51. https://doi.org/10.15587/1729-4061.2018.123852

[9] Jacquet, P.A. On the Anodic Behavior of Copper in Aqueous Solutions of Orthophosphoric Acid. Trans. Electrochem Soc. 1936, 69, 629-656. https://doi.org/10.1149/1.3498234

[10] Patil, Y.; Dulange, S.R. A Review on Electropolishing Process and its Affecting Parameters International. IJARSE 2014, 3, 246-252. [11] Elmalah, N.M.; Abd Elhaliem, S.M.; Ahmed, A.M.; Ghozy, S.M. Effect of Some Organic Aldehydes on the Electropolishing of Copper in Phosphoric Acid. Int. J. Electrochem. Sci. 2012, 7, 7720-7739. [12] L,i D.; Li, N.; Xia, G.; Xiao N.; Zheng, Z.; Zhai, W.; Wu, G. Effect of Sodium Dodecyl Sulfate on Copper Anodic Dissolution in 
Phosphoric Acid Solution. Int. J. Electrochem. Sci. 2012, 7, 92719277.

[13] Huo, J.; Solanki, R.; McAndrew, J. Electrochemical Polishing of Copper for Microelectronic Applications. Surf. Eng. 2003, 19, 11-16. https://doi.org/10.1179/026708402225010047

[14] Ahmed, A.M.; Abd El-Haleem, S.M.; Saleh, M.G.A.; AbdelRahman, A.A.-H. Cooper Electropolishing in the Presence of Purine Derivatives. Asian J. Chem. 2013, 25, 1512-1520.

[15] Taha, A.A.; Ahmed, A.M.; Abdel Rahman, H.H.; Abouzeid, F.M. The Effect of Surfactants on the Electropolishing Behavior of Copper in Orthophosphoric Acid. Appl. Surf. Sci. 2013, 277, 155-166. https://doi.org/10.1016/j.apsusc.2013.04.017

[16] Batouti, M.E.; Ahmed, A.-M.M: Study of Electrochemical Behavior of Copper in Presence of Dicarboxylic and Tricarboxylic Acids. Rev. Roum. Chim. 2015, 60, 1047-1058.

[17] Liu S.-H., Shieh J.-M, Chen C.; Hensen, K.; Cheng, S.-S. Roles of Additives in Damascene Copper Electropolishing. J. Electrochem. Soc. 2006, 153, C428-C433. https://doi.org/10.1149/1.2193348 [18] Mounir, F.; Issami El, S.; Bazz,i Lh.; Salghi, R.; Bammou, L.; Bazzi, L.; Chihab Eddine, A.; Jbara, O. Copper Corrosion Behavior in Phosphoric Acid Containing Chloride and its Inhibition by Artemisia Oil. IJRRAS 2012, 13, 574-587.

[19] Pircher, E.; Martínez, M.R.; Hansal, S.; Hansal, W.

Electropolishing of Copper Alloys in Phosphoric Acid Solutions with Alcohols. Plating Surf. Finishing 2003, 90, 74-79.

[20] Taha A.A.; Sallam S.A.; Ahmed A.M. Corrosion of Copper in Phosphoric Acid $\square$ Ethanol Mixture. Anti-Corros. Method. M. 1994, 41, 10-16. https://doi.org/10.1108/eb007342

[21] Attia, A.A.; Elmelegy, E.M.; Batouti, M.E.; Ahmed, A.-M.M. Studying Copper Electropolishing Inhibition in Presence of Some Organic Alcohols. Port. Electrochim. Acta 2016, 34, 105-118. https://doi.org/10.4152/pea.201602105

[22] Zhao, J.; Kunieda, M.; Yang, G.; Yuan, X.-M. Effects of Electrolyte Formulas on Electrochemical Polish Planarization of Pure Copper. Key Eng. Mat. 2010, 447-448, 159-163.

[23] Awad, A.M.; Ghany, N.A.A.; Dahy, T.M. Removal of Tarnishing and Roughness of Copper Surface by Electropolishing Treatment. Appl. Surf. Sci. 2010, 256, 4370.

https://doi.org/10.1016/j.apsusc.2010.02.033

[24] Abdel-Haleem, S.M.; Ahmed, A.M.; Shadad, M.I. Kinetic Study of Anodic Corrosion of Copper in Phosphoric Acid and Effects of Some Phenols Derivatives. Asian J. Chem. 2013, 25, 9693-9700. https://doi.org/10.14233/ajchem.2013.15132

[25] Du, B.; Suni, I.I. Mechanistic Studies of Cu Electropolishing in Phosphoric Acid Electrolytesю J. Electrochem. Soc. 2004, 151, C375C378. https://doi.org/10.1149/1.1740783

[26] Silchenko, D.; Pilipenko, A.; Pancheva, H.; Khrystych, O.; Chyrkina, M.; Semenov, E. Establishing the Patterns in Anode Behavior of Copper in Phosphoric Acid Solutions when Adding Alcohols. EEJET 2018, 4, 35-41. https://doi.org/10.15587/17294061.2018.140554

[27] Ding, L.; Wu, P.; Cheng, J.; Niu, Y.; Song, Z.; Kong, X. Electrochemical Oscillations during Electro-oxidation of Copper Anode in Phosphoric Acid Solution. Electrochemistry (Tokyo) 2019, 87, 14-19. https://doi.org/10.5796/electrochemistry.18-00002 [28] Demeev, B.B.; Dauletbay, A.; Nauryzbaiev, M.K. The Effect of Organic Surface-Active Additives Upon the Kinetics of Electrodeposition of Ultrafine Copper Powder. Chem. Eng. Trans. 2016, 47, 211-216. https://doi.org/10.3303/CET1647036 [29] Kwon, G.D.; Kim, Y.W.; Moyen, E.; Keum, D.H.; Lee, Y.H.; Baik, S.; Pribat, D. Controlled Electropolishing of Copper Foils at Elevated Temperature. Appl. Surf. Sci. 2014, 307, 731-735. https://doi.org/10.1016/j.apsusc.2014.04.144
[30] Elmalah, N.M.; Elhaliem, S.M.A.; Ahmed A.M.; Ghozy S.M. Effect of Some Organic Aldehydes on the Electropolishing of Copper in Phosphoric Acid. Int. J. Electrochem. Sci. 2012, 7, 7720-7739. [31] Li, D.; Li, N.; Xia, G.; Zheng, Z.; Wang, J.; Xiao, N.; Zhai, W.; Wu, G. An in-situ Study of Copper Electropolishing in Phosphoric Acid Solution. Int. J. Electrochem. Sci. 2013, 8, 1041-1046.

[32] Smirnova, O.; Brovin, A.; Pilipenko, A.; Zhelavska, Yu. Studying the Kinetics of Electrode Reactions on Copper, Silver and Gold in Acid Thiourea-Citrate Electrolytes. Mater. Today Proceed. 2019, 6, 141-149. https://doi.org/10.1016/j.matpr.2018.10.087 [33] Sincheskul, A.; Pancheva, H.; Loboichenko, V.; Avina, S.; Khrystych, O.; Pilipenko, A. Design of the Modified Oxide-Nickel Electrode with Improved Electrical Characteristics. EEJET 2017, 5, 23-28. https://doi.org/10.15587/1729-4061.2017.112264

[34] Ahmed, A.-M.M.; Batouti, M.E.; Khelil, S.M.S. Electropolishing of Metallic Surfaces and the Factors Influencing on the Limiting Current. Port. Electrochim. Acta 2015, 33, 105-110.

https://doi.org/10.4152/pea.201502105

Received: September 03, 2020 / Revised: December 14, 2020 / Accepted: March 12, 2021

\section{ДОСЛІДЖЕННЯ ВПЛИВУ БУТАНОЛУ НА АНОДНУ ПОВЕДІНКУ МІДІ У РОЗЧИНАХ ФОСФАТНОЇ КИСЛОТИ}

\begin{abstract}
Анотація. Досліджена анодна поведінка міді у електролітах на основі фосфатної кислоти і бутанолу. Аналіз одержаних поляризачійних залежностей дозволив встановити ділянки знаходження міді у активному $і$ пасивному стані та суміщеного протікання процесів розчинення міді і виділення кисню. Встановлено, щьо бутиловий спирт є інгібітором електродних прочесів на міді $і$ сприяє різкому зниженню густин струму у діапазоні потенціалів аноду до початку виділення кисню. Додавання бутанолу обумовлюе зникнення осиилячій струму, які присутні на поляризаційних залежностях у розчинах фосфатної кислоти. За співвідношення $\mathrm{C}_{4} \mathrm{H}_{9} \mathrm{OH}: \mathrm{H}_{3} \mathrm{PO}_{4}=1: 3$ пасивачія міді у фосфатно-бутанольних електролітах супроводжується появою чіткого піку, який розділяе зони активного $i$ пасивного стану. При подальшому збільшенні співвідношення спирт:кислота пік поступово зменшується. Значення виходів за струмом ВС розчинення міді залежать від анодної густини струму $j_{a} i$ складу електроліту. Збільшення $j_{a}$ приводить до зниження ВC; аналогічний вплив має підвищення вмісту $\mathrm{C}_{4} \mathrm{H}_{9} \mathrm{OH}$. Найбільші значення ВС спостерігаються в діапазоні $j_{a}=0,5-2 \mathrm{~A} \cdot \mathrm{dm}^{-2}$, що відповідають знаходженню міді $y$ активному стані. Отримані залежності швидкості розчинення міді дозволили встановити, щзо зі збільшенням ја до 20 $A \cdot d m^{-2}$ иееи параметр також збільшується. Якість оброблення міді залежсть від густини струму $i$ складу електроліту. $У$ розчинах зі співвідношенням $\mathrm{C}_{4} \mathrm{H}_{9} \mathrm{OH}: \mathrm{H}_{3} \mathrm{PO}_{4}=2: 1$ якість оброблення незадовільна, поверхня неблискуча і має сліди після шліфування. Якісна обробка спостерігається у електролітах зі співвідношенням $\mathrm{C}_{4} \mathrm{H}_{9} \mathrm{OH}: \mathrm{H}_{3} \mathrm{PO}_{4}=1: 2$ і нижче. Полірування $\mathrm{y}$ таких розчинах дає можливість отримати блискучу поверхню міді зі згладженим рельєфом і відсутністю слідів шліфування.
\end{abstract}

Ключові слова: електрохімічне полірування, пасивація, бутиловий спирт, поверхнево-активна речовина, поляризачійна залежність. 